\title{
Sponsorship recall and recognition: The case of the 2007 Cricket World Cup
}

\author{
C. Boshoff* and C. Gerber \\ Department of Business Management, University of Stellenbosch, \\ Private Bag X1, Matieland 7602, Republic of South Africa \\ cboshoff@sun.ac.za
}

Received April 2008

\begin{abstract}
Millions of rands are spent on sponsorship in general every year, and on sports sponsorships in particular. Yet little is known about the effectiveness of this expenditure. In addition, sponsors are often not sure whether only their brands benefit from a sponsorship or whether competing brands in the same product category also benefit from their efforts.
\end{abstract}

\begin{abstract}
In this study an attempt is made to clarify these considerations by comparing both the brand recall and the brand recognition of companies (and brands) who sponsored the 2007 Cricket World Cup. To determine whether brand recall and brand recognition increased during a sponsorship campaign, a quasi-experimental study was conducted by means of a one-group pre-test-post-test design. The data were collected using a convenience sample of 131 undergraduate students.

The results seem to suggest that both the brand recall and the brand recognition levels of the sponsors increased significantly $(\alpha=0,05)$, but that neither the brand recall nor the brand recognition levels of non-sponsor brands increased. The results therefore show that sponsorship does in fact increase brand awareness, by significantly increasing unaided brand recall, as well as increasing brand recognition and that non-sponsoring companies and brands do not benefit indirectly from their competitors' sponsorships in terms of brand recall and brand recognition.
\end{abstract}

*To whom all correspondence should be addressed.

\section{Introduction}

Marketing can be described as a business function facilitating the exchange process between buyers and sellers by examining the needs and wants of consumers, developing a product or service that satisfies these needs, offering it at an appropriate price, making it available at a particular place or through a channel of distribution, and developing a programme of communication to create awareness and interest (Belch \& Belch, 2004: 8). This description of what marketing is shows that the ability to communicate effectively and efficiently with consumers is critical to the success of both the marketing effort and eventually the entire firm. Effective communication between marketer and market is often bedevilled, however, by the sheer volume of communication aimed at consumers. This "bombardment" leads to information overload which hampers communication effectiveness. Marketers are thus constantly faced with the requirement to build awareness and presence both economically and efficiently (Aaker, 1996:174).

Given the incongruous forces of the growing importance of marketing communications on the one hand and the threat of "information overload" on the other hand, marketers are constantly on the look-out for new, ingenious ways to cut through the clutter, and communicate with the chosen target market.
In markets (such as consumer goods) where branding and brand-building are of particular importance to consumers, communication is of critical concern. In these markets branding has emerged as a top management priority because of the growing realisation that brands are often one of the most valuable assets that firms have (Keller \& Lehmann, 2005).

Marketing communications represent the voice of the brand and are a means by which the brand can establish a dialogue with the target markets and build relationships with customers (Kotler, 2003: 283). The way consumers perceive brands is a key determinant of long-term business-consumer relationships (Low \& Lamb, 2000: 1). A brand often provides customers with a way of recognising and specifying a particular product if they want to choose it again or recommend it to others.

The successes of individual brands therefore owe a great deal to the effectiveness of brand communications. Although print and broadcast media have played an important role in building strong brands, other communication methods, such as sponsorships, are now increasingly being used to cut through the clutter referred to earlier (Kotler, 2003:434; Cornwell \& Maignan, 1998:18).

Sponsorship is a means of persuasion that is fundamentally different from traditional communication instruments as it attempts to persuade consumers indirectly (Crimmins \& 
Horn, 1996:12). The use of sport, art, social and environmental sponsorship has gained in importance in the last decade (Walliser, 2003) with total sponsorship expenditures increasing significantly (Cornwell \& Maignan, 1998). The reason for this growth, particularly in sports sponsorship, according to Gwinner (1997:145), is the benefit that it gives multiple opportunities for building a brand.

Sport has evolved into a professional commodity over the years. The growing interest in professional sport has turned it into a lucrative business, generating large revenues annually (Mason \& Cochetel, 2006). Sport players and games have become saleable commodities, offering companies new opportunities to communicate and build their brands (Morgan, 2004). Given the fact that that sport sponsorships are generally more successful than sponsorships of arts or social causes (Walliser, 2003), one can conclude that sport sponsorship is a communications instrument that should be given serious consideration as a commercial investment.

Although sponsorship is a rapidly growing marketing communication medium, there seems to be uncertainty about aspects related to its impact and effectiveness. Cornwell and Maignan (1998) have highlighted the fact that issues such as wear-out and clutter, as well as the differentiating effect of long-term and corporate awareness of sponsorships, still need to be investigated. Against this background this study investigated the effectiveness of sports sponsorship in terms of creating awareness over longer time periods.

Initially this paper focuses on sponsorship and brand awareness, and then on an exposition of the research design used to collect the data. This section is followed by the empirical results and findings, and the paper concludes with a brief discussion of some managerial implications.

\section{Sponsorship and brand awareness}

According to Ye and Van Raaij (2004), building strong brands begins with creating brand awareness. One of the major advantages of using sponsorship as a communication medium is that it can overcome several communication barriers (Erdogan \& Kitchen 1998 in Walliser, 2003). Enhanced awareness has long been one of the key objectives sought by sponsors, and in may cases is still the only benefit sought (Duffy \& Hooper, 2003). Sponsorship activities present multiple opportunities for achieving brand awareness (Gwinner, 1997:145).

Although researchers have so far not agreed upon a generally accepted definition of sponsorship (Walliser, 2003), we define sponsorship as a partnership between a sponsor (e.g. a business) and a property (e.g. a team or a venue). Sponsorship is a potentially powerful form of persuasion (Crimmins \& Horn, 1996:20) and refers to what is essentially a partnership between a sponsor and a property such as a team or a venue (McCauley, 2001:9; Cornwell \& Maignan, 1998:11). In sport, the sponsor (which in most cases is a business firm) exchanges money or products for the right to associate its name, brand or product with a sporting event or participant (Shank, 2002:16; McCauley, 2001:9).

Since many major sports disciplines have became professional over time, there are an ever-increasing number of events or opportunities for organisations to get involved in sponsorship arrangements (Chrislett, 1998: 56). As a result sports sponsorship spending has increased significantly during the last decade (Akaoui, 2007; Mudeliar, 2007: 49). Even in South Africa sport sponsorship increased from US\$460 million in 2003 to US\$685 million in 2006 (Rose, 2007:2; Williams, 2004:19). According to Barros, De Barros and Chadwick (2007:161), the principal driving force behind sponsorship is the opportunity to reach a mass audience to enhance the sponsor's brand image (Boostram, 2001:103) and ultimately increase its brand awareness (Cornwell \& Maignan, 1998: 12).

One of the major goals of marketing is to generate and maintain brand awareness (Macdonald \& Sharp, 2000). Brand awareness refers to the strength of a brand's presence in the consumer's mind (Aaker, 1996) and is an important goal of the marketing communication efforts of a firm (Macdonald \& Sharp, 2003). Brand awareness exerts a significant influence on consumer decision-making, as consumers often simplify their buying by choosing brands that are familiar to them (Hoyer \& Brown, 1990; Macdonald \& Sharp, 2000). Brand awareness is the strength of a brand's presence in the consumer's mind and refers to the extent and ease with which customers recall the brand and can recognise the products and services with which the brand is associated (Keller, 2003; Macdonald \& Sharp, 2003). Brand recall relates to consumers' ability to retrieve the brand from memory when given the product category as a cue (Keller, 2003:466). Brand recognition is the process of perceiving a brand as previously encountered (Hoyer \& Brown, 1990) and relates to consumers' ability to confirm prior exposure to the brand when given the brand as a cue (Keller, 2003:466).

As pointed out above, enhanced brand awareness has long been one of the key objectives sought by sponsors, and is still in many cases the only benefit sought (Duffy \& Hooper, 2003). According to Aaker (1996), the salience of a brand will determine if it is recalled at a key time in the buying process. For sales to be increased by sponsorship, audiences being exposed to the sponsor's communication activities should therefore be able to recognise the brand (Barros et al., 2007:161). This would require that consumers correctly discriminate the brand at a later stage (Aaker, 1996:10-16), which will be indicative of a successful sponsorship campaign.

Once consumers become familiar with a brand, their perceptions of it become more detailed (Chernatony \& McDonald, 2003). However, in most sponsorships the link between a brand and an event or company is not natural, logical or obvious (Crimmins \& Horn, 1996:12). Since there is often no "natural" or obvious link between a sport sponsorship event and the sponsor, the ability of consumers to recall the sponsor signifies a successful sponsorship campaign. In other words, brand recall requires that 
consumers correctly generate the brand from memory when given a relevant cue (Keller, 2003).

\section{Problem statement and objectives}

Sponsorship is the most obvious form of commercialisation in sport (Mason \& Cochetel, 2006:125). Many sponsorship studies have, however, failed to evaluate the adequacy of the different sponsorship objectives, which include the adequacy of sponsorship awareness (Cornwell \& Maignan, 1998:12). The majority of empirical studies evaluating sponsorship awareness have been conducted via tracking measures (Grohs, Wagner \& Vsetecka, 2004, Walliser, 2003), specifically using cross-sectional studies (Barros et al., 2007:165; Jalleh et al., 2002; Crimmins \& Horn, 1996:13).

Furthermore, many of these studies have yielded inconsistent findings. According to Walliser (2003), studies about sponsorship awareness have shown that brands have basic recall levels which rise shortly before and during an event and fall back close to its initial level a few weeks after the event, and that the duration and magnitude of the variation depend on the overall communication effort of the sponsor, while other researchers have found that consumers get confused about official sponsors (Grohs et al., 2004). Mason and Cochetel (2006:125) conducted a study to examine brand awareness before and after a change was made in the sponsorship of an event and found that the original sponsor, rather than the new sponsor, returned the highest level of brand awareness. And even though Tripodi, Hirons, Bednall and Sutherland (2003) found in their experimental study that consumers were aware of sponsors, the results varied considerably depending on the amount of time given to respondents, as well as the amount of prompting done by researchers.

Although some studies have focused on brand awareness related to sponsorships, not one has investigated the brand recall and brand recognition of the sponsor of a major international sporting event before and after the event.

The purpose of this study was therefore to investigate the brand awareness before and after a sponsorship campaign linked to a major international sporting event. Since sponsors are generally more easily accepted in association with sporting events than with arts or social causes (Walliser, 2003), a quasi-experiment was undertaken to measure the brand recall and brand recognition of various 2007 Cricket World Cup sponsors. The objectives of the study were (1) to determine whether sponsor brand recall levels after a sponsorship campaign are higher than they were prior to the campaign; and (2) to determine whether sponsor brand recognition levels after a sponsorship campaign are higher than they were prior to the campaign.

\section{Hypotheses}

Brand awareness refers to the extent and ease with which customers recall and recognise a brand and can identify the products and/or services with which it is associated. Studies of brand awareness enable marketers to quantify levels and trends in customer knowledge (Farris et al., 2006).
Measuring brand awareness requires collecting information on brand knowledge (Hart \& Murphy, 1998; Hoyer \& Brown, 2001), which can be employed to better assess the depth and breadth of brand awareness (Keller, 2003:466). According to Walliser (2003), three broad approaches to measuring sponsorship awareness may be distinguished in the literature, namely measuring to what extent consumers take notice of sponsors; identifying factors influencing sponsor recall; and analysing the internal processes related to recall taking place in the consumer's mind. In this study brand awareness was investigated by conducting a quasiexperiment. To address the objectives of this study, the following hypotheses were formulated (as illustrated in Figure 1):

$\mathrm{H}_{1}$ : Brand recall prior to the 2007 Cricket World Cup is Cup is less than brand recall after the 2007 Cricket World Cup for sponsor brands

$\mathrm{H}_{2}$ : Brand recognition prior to the 2007 Cricket World Cup is less than brand recall after the 2007 Cricket World Cup for sponsor brands

$\mathrm{H}_{3}$ : Brand recall prior to the 2007 Cricket World Cup is the same as brand recall after the 2007 Cricket World Cup for non-sponsor brands

$\mathrm{H}_{4}$ : Brand recognition prior to the 2007 Cricket World Cup is the same as brand recognition after the 2007 Cricket World Cup for non-sponsor brands

\section{Methodology}

\section{Experimental design}

Since sport sponsorships are generally more easily accepted than sponsorships of arts or social causes (Walliser, 2003), sponsors of the 2007 Cricket World Cup were investigated. To determine whether brand recall and brand recognition increased during a sponsorship campaign, a quasiexperimental study was conducted by means of a one-group pre-test-post-test design to collect the raw data. A onegroup pre-test-post-test design is often used for testing changes in marketing phenomena (McDaniel \& Gates, 2002: 252). For instance, pre-test observations are made of a single group of subjects $\left(\mathrm{O}_{1}\right)$ who are exposed to a treatment, and finally a post-test observation is made $\left(\mathrm{O}_{2}\right)$. The treatment effect is estimated by $\mathrm{O}_{2}-\mathrm{O}_{1}$. For purposes of this study, the experimental design is shown symbolically as follows:

$\mathrm{O}_{1} \mathrm{X} \mathrm{O}_{2}$

$\mathrm{O}_{3} \mathrm{X} \mathrm{O}_{4}$

where:

$\mathrm{O}_{1}=$ brand recall prior to the Cricket World Cup;

$\mathrm{O}_{2}=$ brand recall after the Cricket World Cup;

$\mathrm{O}_{3}=$ brand recognition prior to the Cricket World Cup;

$\mathrm{O}_{4}=$ brand recognition after the Cricket World Cup; and $\mathrm{X}=$ the event sponsorship. 


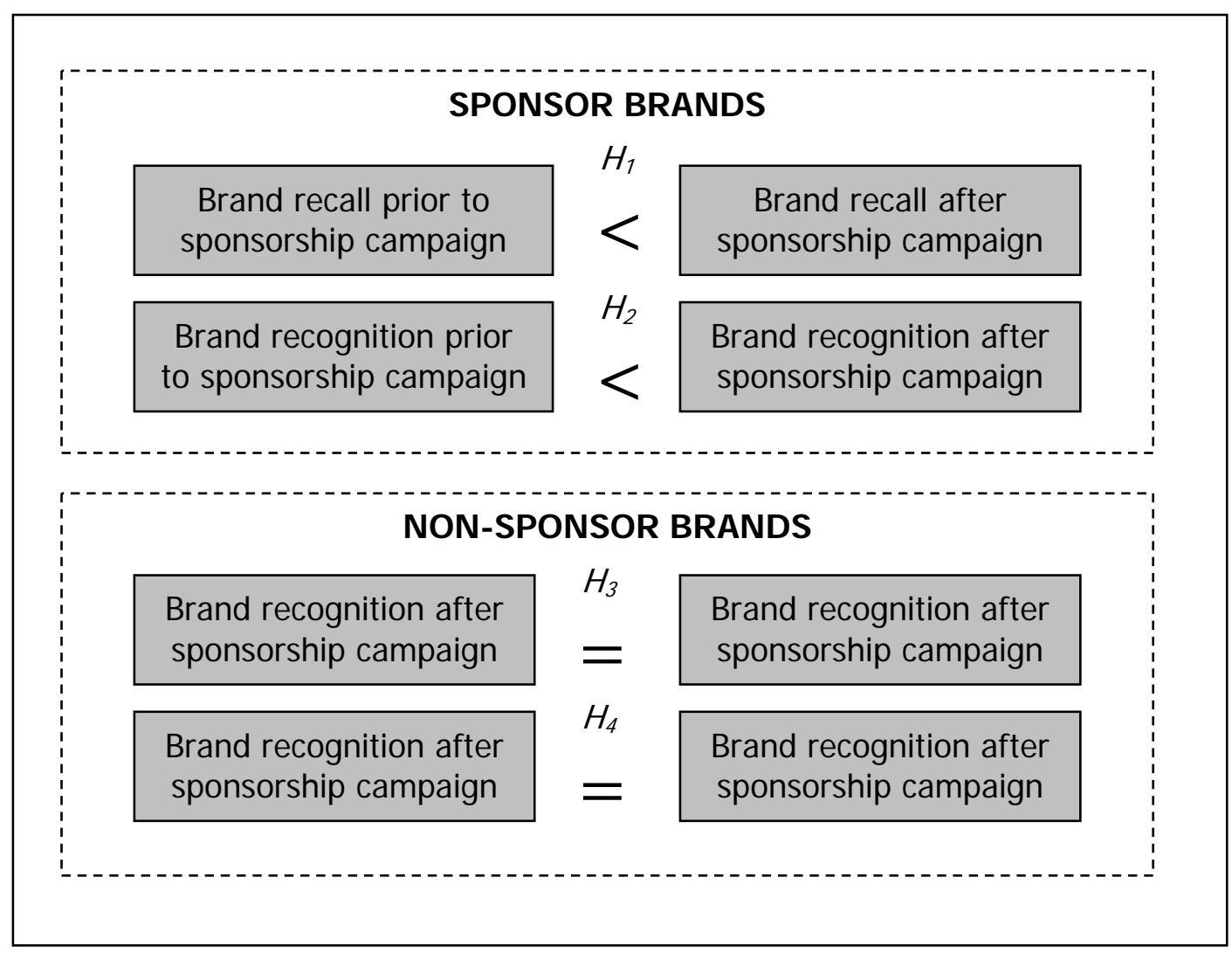

Figure 1: Summary of hypotheses

\section{The sponsors}

The 2007 Cricket World Cup had various event and broadcast sponsors, who included LG Electronics, Pepsi, Hero Honda, Hutch, Indian Oil Corporation, Cable and Wireless, Visa Cards, Scotia Bank, Johnnie Walker and Red Stripe (Sports, 2007). Brands such as Indian Oil Corporation, Cable and Wireless, Scotia Bank, Red Stripe, Hutch and Hero Honda are unfamiliar brands in South Africa, and were therefore not included in the study. The South African broadcast sponsor, Standard Bank, was, however, included in this study (ICC, 2007). A total of five event and broadcast sponsors (LG Electronics, Visa Cards, Johnnie Walker, Pepsi and Standard Bank) were therefore selected for inclusion in the study. Since LG Electronics was the main event sponsor, a major South African home appliance brand (AEG) was selected as the non-sponsor brand.

For both pre- and post-test observations a structured questionnaire was used to measure brand recall on an ordinal scale, and brand recognition on a nominal scale. Behavioural as well as demographic data were also collected. To ensure validity, all brand marks used in the study were printed in their original brand colours.

\section{Sampling}

A convenience sample of undergraduate students studying a variety of different subjects and courses at one university participated in the study. During the pre-test phase of the study 245 questionnaires were completed. However, only 131 participated in the post-test.

\section{Measures}

Since brand recall relates to consumers' ability to retrieve the brand from memory when given the product category as a cue, brand recall was measured by presenting respondents with six product categories in which they had to rank three brand names for each product category. Each brand mentioned was then coded as follows: 3 for a first mention, 2 for a second mention, 1 for a third mention and 0 for no mention. A brand awareness score was then calculated by weighing the frequencies of first mention, second mention, third mention and no mention $\left(\overline{\mathrm{x}}=\frac{\sum \mathrm{wX}}{\sum \mathrm{w}}\right)$.

Brand recognition is the process of perceiving a brand as previously encountered, and was therefore investigated by giving respondents only the brand mark (not the brand name or the slogan). From the options given, respondents had to correctly identify the product category, as well as the industry. Respondents also had to write down the brand's slogan.

Thus brand recognition was measured using three items:

1. Correctly identifying a brand's product category

2. Correctly identifying the industry in which the brand is competing 
3. Correctly describing the brand slogan.

The maximum brand recognition score that a respondent could return was therefore 3 . This score was regarded as interval data.

\section{Data collection}

In the one-group pre-test-post-test experiment, 245 respondents completed the questionnaire one week prior to the 2007 Cricket World Cup. One hundred and thirty-three (133) respondents who participated in the pre-test as well, completed the same questionnaire three weeks after the 2007 Cricket World Cup. Owing to attrition, only these 133 complete observations could be used for data analysis purposes.

\section{Results}

\section{The realised sample}

The sample consisted of $47 \%$ males and $53 \%$ females. The average age of the respondents were 21 years $(s=1.5$; $19 \leq \mathrm{x} \leq 28)$. The majority of the respondents $(70 \%)$ indicated that they were interested in cricket $(\bar{x}=3.98$; $s=1.067 ; 1 \leq \mathrm{x} \leq 5)$, but only $38 \%$ indicated that they were actually cricket supporters $(\overline{\mathrm{x}}=2.99 ; s=1.333 ; 1 \leq \mathrm{x} \leq 5)$. On average respondents watched nine hours television a week $(s=8.08 ; 0 \leq \mathrm{x} \leq 40)$.

\section{Hypothesis testing: Brand recall of sponsor brands}

The first hypothesis tested was:

$\mathrm{H}_{1}$ : Brand recall prior to the 2007 Cricket World Cup is less than brand recall after the 2007 Cricket World Cup for sponsor brands

Since unaided brand awareness was used to investigate brand recall, a weighted mean $\left(\overline{\mathrm{x}}_{\mathrm{W}}\right)$ was computed for each sponsor brand. The difference between the pre- and posttest means was calculated for each brand, using either the one-tailed z-test for proportions or the Wilcoxon signedranked test. The Wilcoxon signed-rank test is used when the magnitudes of differences in ordinal rankings are compared (Zikmund, 2003: 543) and does not require the condition of normality (Bluman, 2004: 640, Agresti, 2002: 90). Table 1 provides a summary of the results for the sponsor brands.

Table 1: Brand recall: sponsor brands

\begin{tabular}{l|c|c|l}
\hline Sponsor brands & $\begin{array}{c}\text { Pretest } \\
\overline{\mathrm{X}}_{\mathrm{W}}\end{array}$ & $\begin{array}{c}\text { Posttest } \\
\overline{\mathrm{X}}_{\mathrm{W}}\end{array}$ & Test statistic \\
\hline $\begin{array}{l}\text { Brand recall: } \\
\text { LG }\end{array}$ & 26,5 & 39,5 & $\begin{array}{l}\mathrm{Z}=-237,7 ; \\
\mathrm{p}<0,05\end{array}$ \\
\hline $\begin{array}{l}\text { Brand recall: } \\
\text { Visa }\end{array}$ & 45,0 & 58,3 & $\begin{array}{l}\mathrm{Tn}=36 ; \\
\mathrm{p}<0,05\end{array}$ \\
\hline $\begin{array}{l}\text { Brand recall: } \\
\text { Johnny Walker }\end{array}$ & 17,7 & 34,0 & $\begin{array}{l}\mathrm{Tn}=20 ; \\
\mathrm{p}<0,05\end{array}$ \\
\hline $\begin{array}{l}\text { Brand recall: } \\
\text { Pepsi }\end{array}$ & 31,5 & 35,5 & $\begin{array}{l}\mathrm{Tn}=42 ; \\
\mathrm{p}<0,05\end{array}$ \\
\hline $\begin{array}{l}\text { Brand recall: } \\
\text { Standard Bank }\end{array}$ & 38,7 & 40,8 & $\begin{array}{l}\mathrm{Z}=-38,03 ; \\
\mathrm{p}<0,05\end{array}$ \\
\hline
\end{tabular}

Based on the results in Table 1 we can conclude that the hypothesis, namely that brand recall prior to the Cricket World Cup is less than brand recall after the Cricket World Cup for sponsor brands, is rejected. In other words, sponsorship of the 2007 Cricket World Cup did in fact increase brand recall after the sponsored event, compared to before the event.

\section{Hypothesis testing: Brand recognition of sponsor brands}

The second hypothesis addressed was:

$\mathrm{H}_{2}$ : Brand recognition prior to the 2007 Cricket World Cup is less than brand recall after the 2007 Cricket World Cup for sponsor brands

This study attempted to measure brand recognition before and after a sponsorship campaign by giving respondents the sponsor brand mark, and asking them to correctly indicate the product category and industry from a list of options, as well as giving the slogan for the company. The idea was to calculate a pre- and post-brand recognition score for each sponsor brand and the dummy brand. However, the brands were so well known to the respondents that the majority correctly identified the product and industry category prior to the sponsorship campaign. It was therefore decided to use only the brand slogan as a measure for pre- and post-test brand recognition. To determine whether there were any significant differences between the pre- and post-test brand recognition, a one-tailed z-test for proportions or chi-square test were performed. The one-tailed $\mathrm{z}$-test for proportions is the appropriate test to use when the population is normally distributed; chi-square, on the other hand, does not require the condition of normality (Diamantopoulos \& Schlegelmilch, 2002:107). Table 2 provides a summary of the results for brand recognition for the sponsor brands.

Table 2: Brand recognition: sponsor brands

\begin{tabular}{l|c|c|l}
\hline Sponsor Brands & Pretest & Posttest & Test statistic \\
\hline $\begin{array}{l}\text { Brand recognition: } \\
\text { LG }\end{array}$ & $37,9 \%$ & $57,6 \%$ & $\begin{array}{l}\mathrm{x}^{2}=127 ; \\
\mathrm{p}<0,05\end{array}$ \\
\hline $\begin{array}{l}\text { Brand recognition: } \\
\text { Visa }\end{array}$ & $0 \%$ & $2,3 \%$ & $\begin{array}{l}\mathrm{x}^{2}=81 ; \\
\mathrm{p}<0,05\end{array}$ \\
\hline $\begin{array}{l}\text { Brand recognition: } \\
\text { Johnny Walker }\end{array}$ & $65,2 \%$ & $83,3 \%$ & $\begin{array}{l}\mathrm{x}^{2}=12,8 ; \\
\mathrm{p}<0,05\end{array}$ \\
\hline $\begin{array}{l}\text { Brand recognition: } \\
\text { Pepsi }\end{array}$ & $0 \%$ & $0,8 \%$ & $\begin{array}{l}\mathrm{Z}=-4,5 ; \\
\mathrm{p}<0,05\end{array}$ \\
\hline $\begin{array}{l}\text { Brand recognition: } \\
\text { Standard Bank }\end{array}$ & $10,6 \%$ & $31,1 \%$ & $\begin{array}{l}\mathrm{x}^{2}=119,3 ; \\
\mathrm{p}<0,05\end{array}$ \\
\hline
\end{tabular}

From Table 2 it is evident that the null hypothesis, namely that brand recognition (as measured by the correct identification of the slogan of the brand) prior to the sponsorship campaign is less than brand recognition after the Cricket World Cup for sponsor brands, must be rejected. In other words, sponsorship of the 2007 Cricket World Cup did in fact increase brand recognition after the sponsored event, compared to before the event. 
Hypothesis testing: Brand recall of non-sponsor brands

In an attempt to control for random responses from respondents and to provide some evidence of internal validity, several non-sponsor brands were included in the study. The basic argument was that if we could confirm that non-sponsor brands did not benefit from the sponsoring activities of actual sponsors, it would suggest that the improved brand recall and brand recognition of sponsors (Tables 1 and 2) were attributable to the "treatment" in this quasi-experimental study, namely the sponsorship of the event.

Therefore, the third hypothesis considered was:

$\mathrm{H}_{3}$ : Brand recall prior to the Cricket World Cup is the same as brand recall after the 2007 Cricket World Cup for non-sponsor brands

A weighted mean $\left(\bar{x}_{\mathrm{w}}\right)$ was computed for each brand listed by respondents. The non-sponsor brands that were selected in this study were the brands with the highest weighted mean. The difference between the pre-and post-test means was calculated for each brand, also using either the onetailed z-test for proportions or the Wilcoxon signed-raked test. The difference between the pre- and post-test means was calculated for each brand (i.e. sponsor and dummy brands)

Table 3: Brand recall: non-sponsor brands

\begin{tabular}{l|c|c|l}
\hline $\begin{array}{l}\text { Non-sponsor } \\
\text { brands }\end{array}$ & $\begin{array}{l}\text { Pretest } \\
\overline{\mathrm{X}}_{\mathrm{w}}\end{array}$ & $\begin{array}{l}\text { Post-test } \\
\overline{\mathrm{x}}_{\mathrm{w}}\end{array}$ & Test statistic \\
\hline $\begin{array}{l}\text { Brand recall: } \\
\text { Defy }\end{array}$ & 20,3 & 13,8 & $\begin{array}{l}\mathrm{Tp}=39 ; \\
\mathrm{p}>0,05\end{array}$ \\
\hline $\begin{array}{l}\text { Brand recall: } \\
\text { Mastercard }\end{array}$ & 36,5 & 35,3 & $\begin{array}{l}\mathrm{Z}=21,2 ; \\
\mathrm{p}>0,05\end{array}$ \\
\hline $\begin{array}{l}\text { Brand recall: } \\
\text { Jack Daniels }\end{array}$ & 30,3 & 27,7 & $\begin{array}{l}\mathrm{Z}=51,3 ; \\
\mathrm{p}>0,05\end{array}$ \\
\hline $\begin{array}{l}\text { Brand recall: } \\
\text { Coke Cola }\end{array}$ & 81,5 & 80,7 & $\begin{array}{l}\mathrm{Tp}=14 ; \\
\mathrm{p}>0.05\end{array}$ \\
\hline $\begin{array}{l}\text { Brand recall: } \\
\text { FNB }\end{array}$ & 29,2 & 27,8 & $\begin{array}{l}\mathrm{Z}=26,2 ; \\
\mathrm{p}>0,05\end{array}$ \\
\hline
\end{tabular}

From Table 3 it is evident that the brand recall levels of the non-sponsor brands after the event did not differ significantly from brand recall prior to the 2007 Cricket World Cup. The null hypothesis is therefore not rejected, and one can conclude that only sponsored brands' recall levels increased significantly during and after the 2007 Cricket World Cup.

\section{Hypothesis testing: Brand recognition of non- sponsor brands}

$\mathrm{H}_{4}$ : Brand recognition prior to the 2007 Cricket World Cup is the same as brand recognition after the 2007 Cricket World Cup for non-sponsor brands

None of the respondents could mention the brand slogan of the non-sponsor brand before and after the 2007 Cricket World Cup campaign, and no test was thus performed on the non-sponsor brand. Although we could not statistically address this hypothesis one can conclude that the brand recognition of the non-sponsor brands did not increase during and after the 2007 Cricket World Cup campaign.

\section{Conclusion}

One of the major goals of marketing is to generate and maintain brand awareness (Macdonald \& Sharp, 2000), and sponsorships present multiple opportunities for enhancing this awareness (Gwinner, 1997). Enhanced awareness has long been one of the key objectives sought by sponsors and is still, in many cases, the only benefit sought (Duffy \& Hooper, 2003).

Although sponsorship is a rapidly growing marketing instrument, Cornwell and Maignan (1998) argue that issues such as wear-out and clutter, as well as differentiating longterm and corporate awareness of sponsorship, still need to be investigated. Consumers are bombarded with increasingly more marketing messages. Their degree of brand awareness depends on their ability to recall any promotional messages and the brand's availability (Chernatony \& McDonald, 2003). This study investigated sponsorship awareness of the 2007 Cricket World Cup by conducting a quasi-experiment on brand recall and brand recognition levels of respondents before and after the 2007 Cricket World Cup. It was found that both the brand recall and the brand recognition levels of the sponsors increased significantly, but that neither the brand recall nor the brand recognition levels of non-sponsor brands increased significantly.

The conclusion that basic brand recall levels rise shortly before and during a sponsored event and fall back close to their initial levels a few weeks after the event (Grohs et al., 2004) could not be confirmed. This study has shown that the brand awareness of sponsored brands does indeed increase weeks after the sponsored event. In other words, sponsorship does in fact increase brand awareness, by significantly increasing unaided brand recall, as well as increasing brand recognition

\section{Limitations of the study}

This study is not without its limitations. Since a one-group pre-test-post-test experimental design was used, maturation might have influenced the findings of the study.

In addition it must be acknowledged that a convenience sample, and more specifically a student sample, was used to collect the data. One of the disadvantages of using a convenience sample is that results cannot be generalised (Diamantopoulos \& Schlegelmilch, 2000:13). A considerable amount of research conducted in marketing is based on university students as respondents and, in particular, for laboratory-like experiments such as this study. In 1972, Enis, Cox and Stafford (1972) reported that, of the consumer behaviour studies conducted at the time, as many as $50 \%$ of them employed one or more student samples. Cunningham, Anderson and Murphy (1974) reviewed a variety of business journals and reported that between $20 \%$ and $33 \%$ of consumer research studies used student subjects. 
Permut, Michel and Joseph (1976) conducted a review of articles in the Journal of Marketing Research over a 10-year period and found that, from 1964-1974, students were the most common sampling category, accounting for $22 \%$ of the samples studied.

Burnett and Dunne (1986) examined the major marketing journals and found that from 1979-1983, approximately $17 \%$ used students as subjects. Based on these findings, one could assume that the over-reliance on student samples has been diminishing. However, a brief review of recent marketing journals would suggest that this decline is no longer evident, as students continue to appear to be a common sample in many studies.

As with any type of convenience sample, the use of student subjects has the inherent advantage of being simple and economical in terms of time, distance and cost. The use of a convenience sample means that selection costs are minimal, because sampling can be undertaken quickly and simply. Furthermore, students tend to be more compliant, cooperative and willing to participate than other subjects, either because they feel obliged to do so, or they have little choice, as it is compulsory, or they believe it is expected of them. These factors result in a high participation rate. Generally, the dilemma facing researchers is the trade-off between cost, time and information requirements.

Other authors disagree with the use of student samples in marketing research, claiming it to be a disreputable procedure (Enis, Cox and Stafford, 1972). They argue that because students typically differ psychologically, socially and demographically from the general population, they constitute inappropriate sample, and therefore research findings based on student samples are not generalisable.

Given the nature of the study and in particular its experimental nature, a major concern was maturation -- too many people dropping out during the two-month duration of the study. A convenience sample consisting of people who were geographically relatively concentrated (such as on a university campus) proved to be an acceptable way of overcoming the threat of maturation. To illustrate the problem: of the 245 respondents who participated in the pretest, 114 or $53,9 \%$ dropped out before the post-test could be completed.

Despite these limitations, and given the exploratory nature of the study, a student sample was regarded as a practical, convenient alternative.

\section{Future research}

The limitations described above leave scope for future follow-up studies to be conducted to overcome these limitations. Such studies could be extended to explore the relationship between brand awareness following a sponsorship and the resultant (if any) brand loyalty.

\section{References}

Agresti, A. 2002. Categorical data analysis. $2^{\text {nd }}$ Edition. Gainesville, FL: Wiley-Interscience.

Akaoui, J. 2007. 'Brand experience on the pitch: How the sponsors fared in the World Cup', Journal of Advertising Research, June: 147-157.

Aaker, D.A. 1996. Building strong brands. London: Free Press.

Barros, C.P., De Barros, C., Santos, A. \& Chadwick, S. 2007. 'Sponsorship brand recall at the Euro 2004 Soccer Tournament', Sport Marketing Quarterly, 16(3): 161-170

Belch, G.E. \& Belch, M.A. 2004. Advertising and promotion: An integrated marketing communications perspective. Boston, MASS: McGraw-Hill.

Bluman, A.G. 2004. Elementary statistics: A step-by-step approach. Boston, MASS: McGraw-Hill.

Boostram, K.S. 2001. 'American sports, media and branding'. MA thesis, Graduate School of Syracuse University.

Burnett, J.J. \& Dune, P.M. 1986. 'An appraisal of the use of student subjects in marketing research', Journal of Business, 14(4): 329-343.

Chrislett, D. 1998. 'Smart money's on sport', Marketing Mix, 17(10): 53-56.

Crimmins, J. \& Horn, M. 1996. 'Sponsorship: From management ego trip to marketing success', Journal of Advertising Research, 36(4): 11-21.

Cornwell, T.B. \& Maignan, I. 1998. 'An international review of sponsorship research', Journal of Advertising, 27(1): 1-21.

Cunningham, W.H., Anderson, W.T. \& Murphy, J.H. 1974. 'Are students real people?' The Journal of Business, 47(3): 399-409.

De Chernatony, L. \& McDonald, M. 2003. Creating powerful brands. London: Butterworth Heinemann.

Diamantopoulos, A. \& Schlegelmilch, B.B. 2002. Taking the fear out of data analysis. London: Thomson.

Duffy, N. \& Hooper, J. 2003. Passion branding. West Sussex: Wiley.

Enis, B.M., Cox, K.K. \& Stafford, J.E. 1972. 'Students as subjects in consumer behavior experiments', Journal of Marketing Research, 9(1): 72-74.

Grosh, R., Wagner, U. \& Vsetecka, S. 2004. 'Assessing the effectiveness of sport sponsorships - an empirical examination', Schmalenbach Business Review, April 56: 119-138. 
Farris, P.W., Bendle, N.T., Pfeifer, P.E. \& Reibstein, D.J. 2006. Marketing metrics: $50+$ metrics every executive should master. Upper Saddle River, NJ: Wharton.

Gwinner, K. 1997. 'A model of image creation and image transfer in event sponsorship', International Marketing Review, 14(2/3): 145.

Hart, S. \& Murphy, J. 1998. Brands the new wealth creators. London: Macmillan.

Hoyer, W.D. \& Brown, S.P. 1990. 'Effects of brand awareness on choice for a common, repeat-purchase product', Journal of Consumer Research, 17: 141-148.

ICC. 2007. ICC Cricket World Cup 2007: Sponsors. [online]

URL:cricketworldcup.indya.com/event/sponsors htm.

Jalleh, G., Donovan, R.J., Giles-Corti, B. \& Holman, D.J. 2002. 'Sponsorships: Impact on brand awareness and brand attitudes', Social Marketing Quarterly, 8(1): 35-45.

Keller, K.L. 2003. Strategic brand management: Building, measuring and managing brand equity. $2^{\text {nd }}$ Edition. Upper Saddle River, NJ: Prentice-Hall.

Keller, K.L. \& Lehmann, D.R. 2005. 'Brands and branding: Research findings and future priorities', Marketing Science Institute Special Report, 5.

Kotler, P. 2003. Marketing management. $11^{\text {th }}$ Edition. Upper Saddle River, NJ: Prentice-Hall.

Low, G.S. \& Lamb, C.W. 2000. 'The measurement and dimensionality of brand associations', The Journal of Product and Brand Management, 9(6): 350-367.

Macdonald, E.K. \& Sharp, B.M. 2000. 'Brand awareness effects on consumer decision making for a common, repeat purchase product: a replication', Journal of Business Research, 48: 31-38.

Macdonald, E.K. \& Sharp, B.M. 2003. 'Management perceptions of the importance of brand awareness as an advertising effectiveness', Marketing Bulletin, 14: 31-38.

McDaniel, C. \& Gates, R. 2002. Marketing research. $5^{\text {th }}$ Edition. New York, NY: John Wiley \& Sons.

McCauley, J. 2001. Sports ... more than just the score. Layton, UT: PSB.

Mason, R.B. \& Cochetel, F. 2006. 'Residual brand awareness following the termination of a long-term event sponsorship and the appointment of a new sponsor', Journal of Marketing Communication, 12(2): 125-144.

Morgen, G. 2004. 'Spending on sport sponsorship? Just think of it as a transfer fee', Marketing Week, Mar: 18.

Mudeliar, T. 2007. 'Marketing through sport', Journal of Marketing, MFSA, Oct/Nov: 48-49.
Permut, S.E., Michel, A.J. \& Joseph, M. 1976. 'The researcher's sample: A review of the choice of respondents in marketing research', Journal of Marketing Research, Aug, 13(3): 278-283.

Rose, R. 2007. 'Sports sponsorship: Crying foul', Financial Mail, October, 12. [online]. URL:

http://secure.financialmail.co.za/07/1012/cover/coverstory $h$ tm.

Shank, M.D. 2002. Sports marketing: A strategic perspective. $2^{\text {nd }}$ Edition. Upper Saddle River, NJ: PrenticeHall.

Sports. 2007. 'Sponsors of Cricket World Cup 2007'. [online]. URL:http://www.iloveindia.com/sports/world-cupcricket-2007/sponsors.html.

Tripodi, J.A., Hirons, M., Bednall, D. \& Sutherland, M. 2003. 'Cognitive evaluation: Prompts used to measure sponsorship awareness', International Journal of Market Research, 45(4): 435-455.

Walliser, B. 2003. 'An international review of sponsorship research: Extension and update', International Journal of Advertising, 22(1): 5-44.

Williams, D. 2004. 'SA sports: no pain, no gain', Financial Mail, February, 13. [online]. URL:

http://secure.financialmail.co.za/04/0213/cover/coverstory h tm.

Ye, G. \& Van Raaij, W.F. 2004. 'Brand equity: Extending brand awareness and liking with signal detection theory', Journal of Marketing Communications, 10(2): 95-114.

Zikmund, W.G. 2003. Business research methods. $7^{\text {th }}$ Edition. New York: Thomson South-Western Publishing. 